\author{
Witold Warcholik \\ Uniwersytet Pedagogiczny \\ im. Komisji Edukacji Narodowej w Krakowie
}

\title{
Finansowanie kształcenia studentów kierunku turystyka i rekreacja ze środków Europejskiego Funduszu Społecznego (na przykładzie Instytutu Geografii UP w Krakowie)
}

\section{Oferta edukacyjna placówek szkolnictwa wyższego a rynek pracy}

Polskie szkolnictwo wyższe w początku XXI wieku zmaga się z licznymi problemami, wśród których do najistotniejszych zalicza się niedostosowanie oferty edukacyjnej do dynamiki zmian na rynku pracy. Od uczelni zawodowych i uniwersytetów oczekuje się wyposażania studentów w takie kompetencje kluczowe, które ułatwią im w przyszłości mobilność na rynku pracy i pozwolą na kierowanie własnym rozwojem zawodowym. Efektywnym narzędziem w realizacji wieloaspektowej modernizacji oferty edukacyjnej stają się stopniowo środki Europejskiego Funduszu Społecznego (Ewaluacja działań podejmowanych na rzecz systemu kształcenia i szkolenia $w$ ramach EFS, 2008).

Gruntowna modernizacja oferty edukacyjnej z wykorzystaniem środków EFS może być realizowana między innymi poprzez otwieranie nowych kierunków studiów i rozwój metodyki kształcenia w kierunku nauczania modułowego oraz opracowania materiałów dydaktycznych ułatwiających nauczanie na odległość. W styczniu 2009 roku w Instytucie Geografii UP rozpoczęto realizację zadania „Uruchomienie nowego kierunku: turystyka i rekreacja” w ramach projektu „Rozwój potencjału dydaktycznego Uniwersytetu Pedagogicznego w Krakowie”, współfinansowanego ze środków Europejskiego Funduszu Społecznego. W pierwszym kwartale realizacji tego trzyletniego projektu grupę 70 studentów studiów niestacjonarnych I stopnia charakteryzowały poniższe statystyki:

- $18 \%$ beneficjentów stanowiły osoby nieaktywne zawodowo,

- $3 \%$ beneficjentów stanowiły osoby bezrobotne,

- $11 \%$ beneficjentów stanowiły osoby zatrudnione w przedsiębiorstwach,

- $1 \%$ beneficjentów stanowiły osoby zatrudnione w rolnictwie,

- $42 \%$ beneficjentów stanowiły osoby z obszarów wiejskich,

- $68 \%$ beneficjentów stanowiły osoby uczące się,

- $4 \%$ beneficjentów stanowiły osoby z wyższym wykształceniem,

- $84 \%$ beneficjentów stanowiły kobiety,

- $89 \%$ beneficjentów stanowiły osoby do 25 . roku życia (średnia wieku wyniosła 23 lata).

\section{Modernizacja oferty edukacyjnej placówek szkolnictwa wyższego wspomagana} środkami EFS na przykładzie Instytutu Geografii UP w Krakowie

Program Operacyjny Kapitał Ludzki, dążąc do efektywnego rozwoju zasobów ludzkich, koncentruje się m.in. na wsparciu sektora edukacji. W zadaniu „Uruchomienie nowego kierunku: turystyka i rekreacja” w ramach w projektu „Rozwój potencjału dydaktycznego Uniwersytetu Pedagogicznego w Krakowie", realizowanym w IG UP w Krakowie, uwage skupiono na dwóch z sześciu głównych celów strategicznych PO KL: 
- upowszechnieniu edukacji społeczeństwa na każdym etapie kształcenia przy równoczesnym zwiększeniu jakości usług edukacyjnych i ich silniejszemu powiązaniu z potrzebami gospodarki opartej na wiedzy,

- podniesieniu poziomu aktywności zawodowej oraz zdolności do zatrudnienia osób bezrobotnych i biernych zawodowo.

Środki pozyskane do realizacji zadania wydatkowane są między innymi na:

- wynagrodzenie kadry dydaktycznej, prowadzącej obowiązkowe dla beneficjentów zajęcia w formie wykładów, ćwiczeń, zajęć w pracowniach i w terenie, a objętej m.in. obowiązkami weryfikacji obecności studentów, opracowania szczegółowych konspektów zajęć i przygotowania materiałów do Pedagogicznej Biblioteki Cyfrowej, zaś po zakończeniu zajęć - poddawanej ocenie poprzez ankiety ewaluacyjne,

- koszty transportu i noclegów studenckich w trakcie zajęć terenowych, obozów itp. Są to środki istotnie rozszerzające wachlarz możliwości praktycznego kształcenia beneficjentów, przykładowo poprzez prowadzenie przez nich wynajętego do tego celu obiektu noclegowego itp.,

- koszty delegacji wykładowców w trakcie prowadzonych zajęć terenowych,

- koszty delegacji za wyjazdy kadry dydaktycznej na targi turystyczne. Środki te umożliwiają zapoznanie beneficjentów z najnowszymi ofertami na rynku turystycznym,

- wynagrodzenie kadry za prowadzone zajęcia wyrównawcze dla beneficjentów, którzy mają problemy z realizacją zaliczeń przedmiotów objętych programem studiów,

- wynagrodzenie koordynatora zadania, będącego w stałym, indywidualnym kontakcie z każdym z beneficjentów, Biurem Funduszy Unijnych, władzami Instytutu i Wydziału, w którym realizowane są studia, prowadzącego stronę internetową zadania i odpowiedzialnego za prawidłową dystrybucję środków EFS.

Fot. 1. Wykłady dla studentów TiR EFS w trakcie pobytu w Niemczech zorganizowanego z wykorzystaniem środków EFS, przy współpracy z Uniwersytetem w Erfurcie

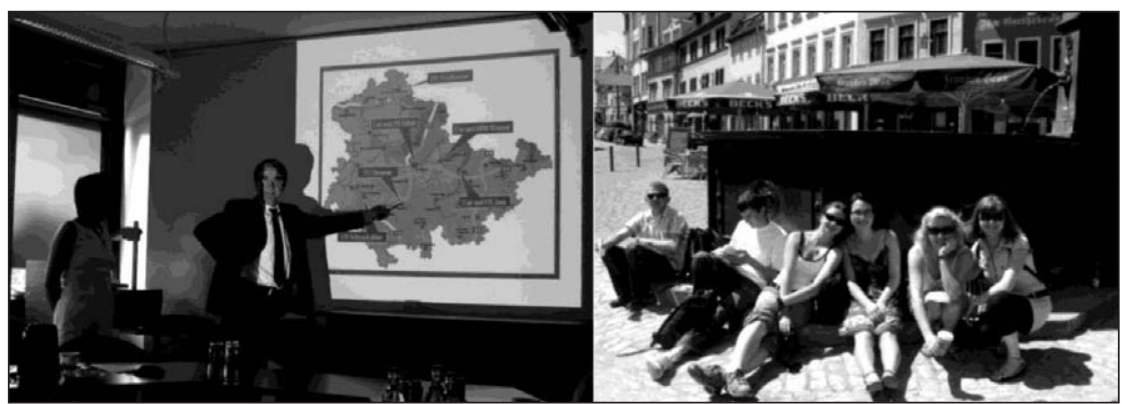

Źródło: fotografie wykonane przez studentów TiR EFS.

W polskim szkolnictwie wyższym coraz częściej jest dostrzegana potrzeba zmian skierowanych na wzrost znaczenia kształcenia umiejętności. Zmiany te następują powoli, a istotne znaczenie, z perspektywy dopasowania systemu kształcenia do wymogów rynku pracy i społeczeństwa opartego na wiedzy, ma rozwój systemu doradztwa zawodowego i szerszy kontakt studentów z branżowymi specjalistami spoza uniwersyteckiej kadry dydaktycznej. Środki pozyskane w ramach EFS umożliwiają przeprowadzenie szeregu wykładów, warsztatów i prelekcji terenowych w kraju i za granicą (fot. 1), prowadzonych przykładowo przez organizatorów ruchu turystycznego, podróżników, ratowników i przedsiębiorców reprezentujących branżę turystyczną. 
Stworzono w ten sposób dobry klimat do rozwoju dalszej współpracy wokół projektów realizowanych w IG UP z lokalnymi partnerami społecznymi oraz kreowania zainteresowania wśród takich instytucji.

W opublikowanych raportach z realizacji zadań finansowanych ze środków unijnych, dotyczących oceny wpływu wsparcia ukierunkowanego na zapewnienie nowoczesnego wyposażenia placówek edukacyjnych, podkreśla się wyraźnie wysoką adekwatność projektów wyposażających placówki w sprzęt komputerowy i oprogramowanie. W ramach zadania realizowanego w Instytucie Geografii UP w Krakowie pozyskano wielostanowiskowe wersje oprogramowania z zakresu Systemów Informacji Geograficznej (Idrisi) oraz komputerowej organizacji biur turystycznych (Kameleon), zainstalowane w Pracowni GIS IG UP. Stanowią one efektywne narzędzia kształcenia studentów dla potrzeb branży turystycznej, m.in. zarządzania w turystyce oraz organizacji ruchu turystycznego. Ze środków EFS powiększono zasoby Instytutu Geografii o cyfrowe mapy wielkoskalowe, a beneficjentom przekazano analogowe mapy turystyczne, wykorzystywane m.in. w trakcie pieszych i rowerowych obozów terenowych (fot. 2). Beneficjenci kształcący się w ramach specjalizacji pilotaż i przewodnictwo zostali wyposażeni na zajęciach terenowych w pozyskane ze środków EFS ręczne nawigatory GPS oraz PDA z oprogramowaniem umożliwiającym nawigowanie autobusu w trakcie wyjazdowych zajęć metodycznych. Znacznym ułatwieniem dla wykładowców była dostępność przenośnego zestawu multimedialnego, przy określonej specyfice kierunku turystyka i rekreacja, umożliwiającego prowadzenie zajęć terenowych i wykładów w trakcie wyjazdowych praktyk studenckich. Związek pomiędzy wsparciem w narzędzia informatyczne a przygotowaniem do wymogów rynku pracy jest niezaprzeczalny, a funkcjonowanie we współczesnym społeczeństwie, w tym na rynku pracy, musi uwzględniać sprawne wykorzystywanie technologii informacyjnej. Jakość i nowoczesność zakupionego sprzętu, uzupełniającego zasoby Instytutu Geografii UP, gwarantują szerszy dostęp beneficjentów do takich narzędzi w trakcie zajęć, a poprzez rozszerzenie zakresu umiejętności - wzrost ich konkurencyjności na rynku pracy.

Fot. 2. Studenci TiR EFS $w$ trakcie obozów pieszych i rowerowych realizowanych w ramach środków EFS

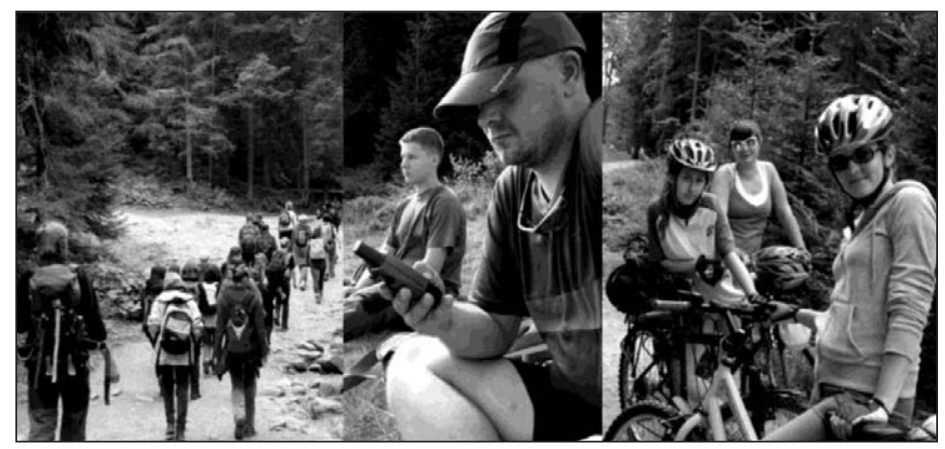

Źródło: fotografie wykonane przez studentów TiR EFS.

Przykładem efektywnego wsparcia ukierunkowanego na zapewnienie nowoczesnego wyposażenia placówek edukacyjnych jest sfinansowanie zakupu nowoczesnych zestawów do szkoleń w zakresie udzielania pierwszej pomocy przedmedycznej w IG UP w Krakowie. Efektywność takich zajęć prowadzonych w Polsce w ramach studiów na kierunku turystyka oraz kursów dla przewodników i pilotów wycieczek, a prowadzonych bez wspomnianego, specjalistycznego sprzętu, jest znikoma. Uatrakcyjnienie form nauczania w Instytucie Geografii UP 
nastąpiło także poprzez umożliwienie wymiany doświadczeń, materiałów źródłowych i scenariuszy zajęć opracowanych przez wykładowców poprzez platformę edukacyjną, jaką jest Pedagogiczna Biblioteka Cyfrowa, której stworzenie jest również efektem projektu zrealizowanego w ramach EFS.

Zaletą programów modułowych jest m.in. możliwość ich różnorodnego zastosowania, ponieważ jednostki modułowe mogą być wykorzystywane w kształceniu studentów na różnych kierunkach studiów, w formach szkolnych i pozaszkolnych, poprzez kursy dokształcające i doskonalące, stacjonarne i niestacjonarne. Pozyskany ze środków EFS nowoczesny sprzęt, materiały i oprogramowanie, po zakończeniu realizacji projektu, będą wielokrotnie wykorzystywane w trakcie zajęć w ramach programów studiów na kierunku geografia oraz turystyka i rekreacja, szkoleniach i kursach dla młodzieży akademickiej i licealnej.

Receptą na sukces projektów, takich jak zadania finansowane ze środków EFS, jest nie tylko dobry pomysł (np. nowe, atrakcyjne studia), ale przede wszystkim zaangażowanie i dobre przygotowanie zespołu, w tym zarówno koordynatorów, jak i zdeterminowanej kadry dydaktycznej. Pracownicy niebiorący wcześniej udziału w tego typu przedsięwzięciach nie zawsze są gotowi na wzajemną współpracę, także z beneficjentami, oraz na pozytywne nastawienie do dodatkowych obowiązków wynikających z realizacji projektu. Nie bez znaczenia pozostają także problemy związane ze specyfiką zadania, jakim są studia wyższe. Przykładowo - beneficjenci projektu, zobowiązani do uczestnictwa we wszystkich zajęciach projektowych, są często równocześnie absolwentami innych kierunków studiów, z zaliczonymi już wymaganymi w projekcie przedmiotami, nierzadko w większym wymiarze godzin, legitymującymi się stosownymi wpisami w indeksach, w tym punktami ECTS. Wnioski z badań ankietowych prowadzonych wśród koordynatorów projektów EFS wskazują, że większość realizatorów takich zadań może się pochwalić bogatym doświadczeniem w realizacji podobnych przedsięwzięć (dobry pomysł na projekt rodzi się z wcześniejszej praktyki, refleksji nad wcześniejszymi porażkami i sukcesami oraz chęci stałego podnoszenia jakości usług) (Ciężka 2006). Istotnym atutem omówionego powyżej zadania jest wieloletnie doświadczenie dydaktyczne pracowników zatrudnionych w projekcie oraz ścisła, konstruktywna współpraca pomiędzy koordynatorem projektu a dyrekcją Instytutu Geografii i władzami Wydziału Geograficzno-Biologicznego UP w Krakowie.

Realizacja wsparcia potencjału dydaktycznego uczelni w ramach środków EFS ujawnia wiele problemów związanych z dopasowaniem systemu kształcenia do wymogów rynku pracy i społeczeństwa opartego na wiedzy. Projekt uruchomienia nowego kierunku studiów turystyka i rekreacja w Instytucie Geografii UP w Krakowie pozwala na stopniową i skuteczną minimalizację skali tego problemu. Proces ten wymaga jednak sprawnego współdziałania wielu podmiotów na poziomie jednostki uczelnianej, kierowników katedr, działów nauczania i zamówień publicznych, zaangażowania ze strony pracowników dydaktycznych oraz ścisłej współpracy z Ministerstwem Edukacji Narodowej, Ministerstwem Nauki i Szkolnictwa Wyższego oraz resortem pracy. Dodatkowo, konieczna jest współpraca na poziomie lokalnym z pracodawcami i specjalistami z branży turystycznej.

Beneficjenci większości projektów realizowanych ze środków EFS należą do trudnych grup docelowych. Ich deficyty powodują, że niechętnie decydują się na udział w projekcie oraz dotrwanie do jego finalizacji. W przypadku grupy studentów turystyki i rekreacji istotnym problemem okazała się właściwa organizacja pracy, w znaczącym odsetku są to bowiem studenci dwukierunkowi, a ze względu na specyfikę branży turystycznej, niekiedy osoby okresowo przebywające poza granicami kraju. Współpraca koordynatora i pracowników dydaktycznych z beneficjentami staje się efektywną wyłącznie przy jasno sformułowanych zasadach 
zaliczania poszczególnych semestrów studiów i kwartałów projektu, działaniach mobilizujących i motywujących, dużej wrażliwości, zrozumieniu i indywidualnej trosce o każdego beneficjenta.

Ze względu na fakt, iż ocena wzajemnych oddziaływań rynku pracy i procesu kształcenia jest bardzo złożona i wymaga różnorodnych informacji, dane z przebiegu realizacji projektu powinny być gromadzone w ciagu dłuższego czasu, w którym należy położyć istotny nacisk na autoewaluację. Bez ścisłej analizy informacji zbieranych systematycznie od beneficjentów, dotyczących oczekiwań i opinii o wymiernych efektach kształcenia, nie jest możliwa odpowiedź na pytanie czy dany kierunek kształcenia jest adekwatny do potrzeb rynku pracy.

Skala udzielonej pomocy w obszarze objętym przedstawionym powyżej projektem w stosunku do istniejących złożonych potrzeb rynku turystycznego w Polsce, pozwala na ocenę aktualnego oddziaływania wsparcia środkami EFS jako pomoc doraźną. W efekcie uruchomienia nowego kierunku turystyka i rekreacja w obrębie Uniwersytetu Pedagogicznego został zainicjowany pozytywny trend przeobrażeń w edukacji przyszłych kadr zasilających branżę turystyczną, stanowiący podstawę do podejmowania przez beneficjentów kolejnych inicjatyw z wykorzystaniem środków unijnych.

\section{Literatura}

1. Ciężka B., Chromiak E., Kobylec D., Otko T., 2006, Dobre praktyki EFS w Polsce - pierwsze doświadczenia. Raport z badań, Fundacja Instytut Studiów Strategicznych, Kraków.

2. Ewaluacja działań podejmowanych na rzecz systemu ksztatcenia i szkolenia $w$ ramach EFS, 2008, Raport końcowy przygotowany dla Departamentu Zarzadzania EFS w Ministerstwie Rozwoju Regionalnego, Wyd. Ministerstwo Rozwoju Regionalnego, Warszawa.

\section{Education of Students in Tourism and Recreation Financed by European Social Fund}

The key challenge that Polish higher education needs to face in the early 21 st century is to adjust its educational offer to the dynamic changes taking place within the employment market. Higher vocational schools and universities are expected to provide students with crucial skills that will in the future empower their mobility on the employment market as well as enhance their professional development. The multifaceted modernization of the educational offer could effectively be supported by means of the European Social Fund. The passport to success in such undertakings as launching a new specialization „Tourism and Recreation” within the initiative: „Development of Didactical Potential of The Pedagogical University in Cracow”, financed by ESF, is not only built up on a clever idea (e.g. new, attractive studies) but above all, on committed and well-prepared organizational team. What constitutes the essential factor is the interaction between coordinators along with determined teaching staff, heads of departments, heads of teaching and public procurements divisions, Ministry of Education and Labour, as well as employers and tourism industry experts. The beneficiaries of the projects implemented with the financial support of ESF belong to difficult target groups. Their deficiencies make it hard to stimulate their active participation in the projects and to make them persevere in the given task. 